\title{
The influence of upwelling on the diversity and distribution of marine shrimp (Penaeoidea and Caridea) in two tropical coastal areas of southeastern Brazil
}

\author{
João Alberto Farinelli Pantaleão • Abner Carvalho-Batista • \\ Adilson Fransozo $\cdot$ Rogério Caetano da Costa
}

Received: 20 May 2015/Revised: 30 July 2015/Accepted: 31 July 2015/Published online: 21 August 2015

(C) Springer International Publishing Switzerland 2015

\begin{abstract}
Two coastal locations situated inside and outside an upwelling area were investigated to assess the influence of environmental factors on the structure of marine shrimp assemblages. The locations were Macaé in the state of Rio de Janeiro (RJ), influenced by upwelling from Cabo Frio (RJ), and Ubatuba in the state of São Paulo, with no upwelling. Samples were collected monthly with trawl nets, in three sites in each location at depths of 5-20 m. The relationship between species abundance and environmental factors was tested by redundancy analysis. The total of 148,266 shrimp captured (102,832 from Macaé and 45,434 from Ubatuba) included 15 species, 13 genera, and 7 families. The caridean Periclimenes paivai was collected for the first time on the RJ coast, expanding its known geographical distribution. Higher richness and $J^{\prime}$ and $H^{\prime}$ values were obtained in the location under upwelling influence (Macaé). Environmental
\end{abstract}

Handling editor: Vasilis Valavanis

\footnotetext{
J. A. F. Pantaleão $(\square) \cdot$ A. Carvalho-Batista .

R. C. da Costa

Laboratório de Biologia e Ecologia de Camarões

Marinhos e de Água Doce (LABCAM) - Departamento de

Ciências Biológicas, Faculdade de Ciências, UNESP,

17033-360 Bauru, SP, Brazil

e-mail: pantaleaojaf@gmail.com

A. Carvalho-Batista

e-mail: carvbatis@gmail.com

R. C. da Costa

e-mail: rccosta@fc.unesp.br
}

variables (granulometric composition and organicmatter content of sediment, bottom temperature, and salinity) were associated with the abundance of shrimp. Our results suggest that sediment type and temperature are among the most important variables affecting seasonal distribution of the species. However, other factors such as intraspecific migration might have also influenced the observed patterns.

Keywords Shrimp community · Biodiversity · RDA · Macaé · Ubatuba

\section{Introduction}

Coastal upwelling systems are usually the result of horizontal differences in the surface layer of the ocean, driven by the wind. Thus, denser and colder water, usually rich in nutrients, is transported to the surface, replacing the warmer water, mostly poor in nutrients

\footnotetext{
J. A. F. Pantaleão · A. Carvalho-Batista .

A. Fransozo - R. C. da Costa

Núcleo de Estudos em Biologia, Ecologia e Cultivo de

Crustáceos (NEBECC), Botucatu, SP, Brazil

e-mail: fransozo@ibb.unesp.br

A. Fransozo

Departamento de Zoologia, Instituto de Biociências, UNESP, 18618-000 Botucatu, SP, Brazil
} 
(Lehmann \& Myrberg, 2008). Upwellings are the physical processes that most affect the marine life where they occur (Merino \& Monreal-Gómez, 2009). Although upwelling areas occupy only $1 \%$ of the ocean surface, they contribute about $20 \%$ of the world fisheries productivity (Cury et al., 2000). In Brazil, this phenomenon can be observed in seven locations along the southern and southeastern coast (Vitória, São Tomé, Cabo Frio, São Sebastião, Santa Catarina, Santa Marta, and Rio Grande do Sul) and is most intense off Cabo Frio on the coast of Rio de Janeiro state (RJ) (Coelho-Souza et al., 2012).

The South Atlantic oceanographic circulation has two main water currents: one from the north (Brazil Current), which carries tropical waters characterized by high salinity and temperature (TW; $T>20^{\circ} \mathrm{C}, S>36$ ), and another from the south (Malvinas or Falkland Current), which transports subantarctic waters and is characterized by low salinity and temperature (SAW; $T<15^{\circ} \mathrm{C}, S<34$ ) (Castro-Filho \& Miranda, 1998). Between 30 and $46^{\circ} \mathrm{S}$ latitudes, there is a confluence of these currents, originating a water mass called the South Atlantic Central Water (SACW; $T<18^{\circ} \mathrm{C}, S<36$ ). During certain times of the year, depending both on current and wind intensity (Castro-Filho et al., 1987), horizontal and vertical changes and seasonal mixing between different water masses may occur. This mixing is possible even in coastal areas that are not directly influenced by upwelling (Odebrecht \& Castello, 2001), such as off Ubatuba.

The Ubatuba coastal area has a low coastal plain, with a coastline consisting of small isolated massifs and promontories of the Serra do Mar terminal spurs (Ab'Sáber, 1955). This geomorphology results in a strongly indented coastline with many inlets, which, due to their configuration, are semiconfined (Mahiques, 1995). Ubatuba is an oligomesotrophic location, i.e., with moderate amounts of chlorophyll-a (VegaPérez, 1993). Chlorophyll levels increase particularly during the summer, generally when the intrusion of the SACW occurs.

In general, an upwelling results in transport of nutrients (especially phosphorus and nitrogen) trapped in the lower layers up to the euphotic zone, directly influencing primary productivity (Odebrecht \& Castello, 2001; Gaeta \& Brandini, 2006). The increase in primary productivity can exert a strong influence on the zooplankton and also on the benthic communities, since benthic organisms can use the debris generated by the higher productivity in the euphotic zone (Mann \& Lazier, 1996; Sumida et al., 2005).

Since the Cabo Frio upwelling is responsible for a high degree of biological enrichment, it is of crucial importance for the entire biological community and consequently for the local fishery (Bakun \& Parrish, 1990; Franchito et al., 2008). The local fishery is focused in fishes as the Brazilian sardine [Sardinella brasiliensis (Steindachner, 1879)], the skipjack tuna [Katsuwonus pelamis (Linnaeus, 1758)], and some tuna species (Thunnus spp) and also in penaeidae shrimps (Haimovici et al., 2007). Besides its economic importance in fisheries, shrimps represent a link between their main food sources (organic-matter detritus, small benthic invertebrates, and biofilm) (Branco, 2005) and pelagic predators such as fishes, cephalopods, swimming crabs, and even marine birds (Stevens et al., 1984; Dall et al., 1990; Bugoni \& Vooren, 2004).

The impact of shrimp fishing in coastal locations has caused significant losses in the biomass and biodiversity of non-consolidated environments (Pauly et al, 2002; Castilho et al., 2008) due to the use of fine-meshed bottom trawl nets. This type of fishing encompasses high levels of bycatch, disturbance of the seabed, and severe impacts on the benthic community (Kaiser \& Spencer, 1996; Watling \& Norse, 1998). The lack of knowledge about diversity and abundance, mainly about those assemblages targeted by fishing fleets, decreases the efficiency of measures to protect the stocks of commercially important species (Castilho et al., 2008).

This study investigated how changes in environmental parameters can influence the composition and abundance of shrimps (Penaeoidea and Caridea) in two locations of the Brazilian coast, located within (Macaé, RJ) and outside (Ubatuba, SP) the Cabo Frio upwelling area, by means of multivariate analysis. We worked under the hypothesis that locations influenced by different intensities of SACW upwelling may show marked differences in the distribution, abundance, and composition of their assemblages.

\section{Materials and methods}

\section{Shrimp sampling}

Samples were collected in tropical locations of Brazil's southeast coast: Macaé (Rio de Janeiro State, $22^{\circ} 37^{\prime} \mathrm{S}$ and $041^{\circ} 78^{\prime} \mathrm{W}$ ) and Ubatuba (São Paulo State, $23^{\circ} 27^{\prime} \mathrm{S}$ 
and $045^{\circ} 02^{\prime} \mathrm{W}$ ) (Fig. 1). Three different sites were sampled monthly, in order to minimize the possible effect of local trends in each location. Samples were collected during the day in the two locations concomitantly, from July 2010 through June 2011.

The same type of commercial fishing boat was used for all sampling. Both vessels were $10 \mathrm{~m}$ long, equipped with two otter-trawl nets with 5-m door openings, mesh size $20 \mathrm{~mm}$ and $18 \mathrm{~mm}$ in the cod end. One trawl at each of the three sampling sites was performed in each location, for $1 \mathrm{~h}$ at 2 knots, always from shallower $(5 \mathrm{~m})$ to deeper $(20 \mathrm{~m})$ water. Thus, an area of $37,000 \mathrm{~m}^{2}$ was trawled or $111,000 \mathrm{~m}^{2}$ per month in each study location.
Due to the high number of individuals captured in each trawl and considering the different body sizes of the three more abundant species, Xiphopenaeus kroyeri (Heller, 1862), Artemesia longinaris Spence Bate, 1888, and Pleoticus muelleri (Spence Bate, 1888), distinct random subsamples were taken, of 500, 150, and 300 grams, respectively (accuracy $=0.01 \mathrm{~g}$ ). The number of individuals was counted for each subsample. The total number of individuals in each trawl was estimated from the subsample data and the total biomass. When the biomass of these species did not exceed the weight set for the subsample, all individuals were counted. For the less-abundant species, all the individuals collected were counted.

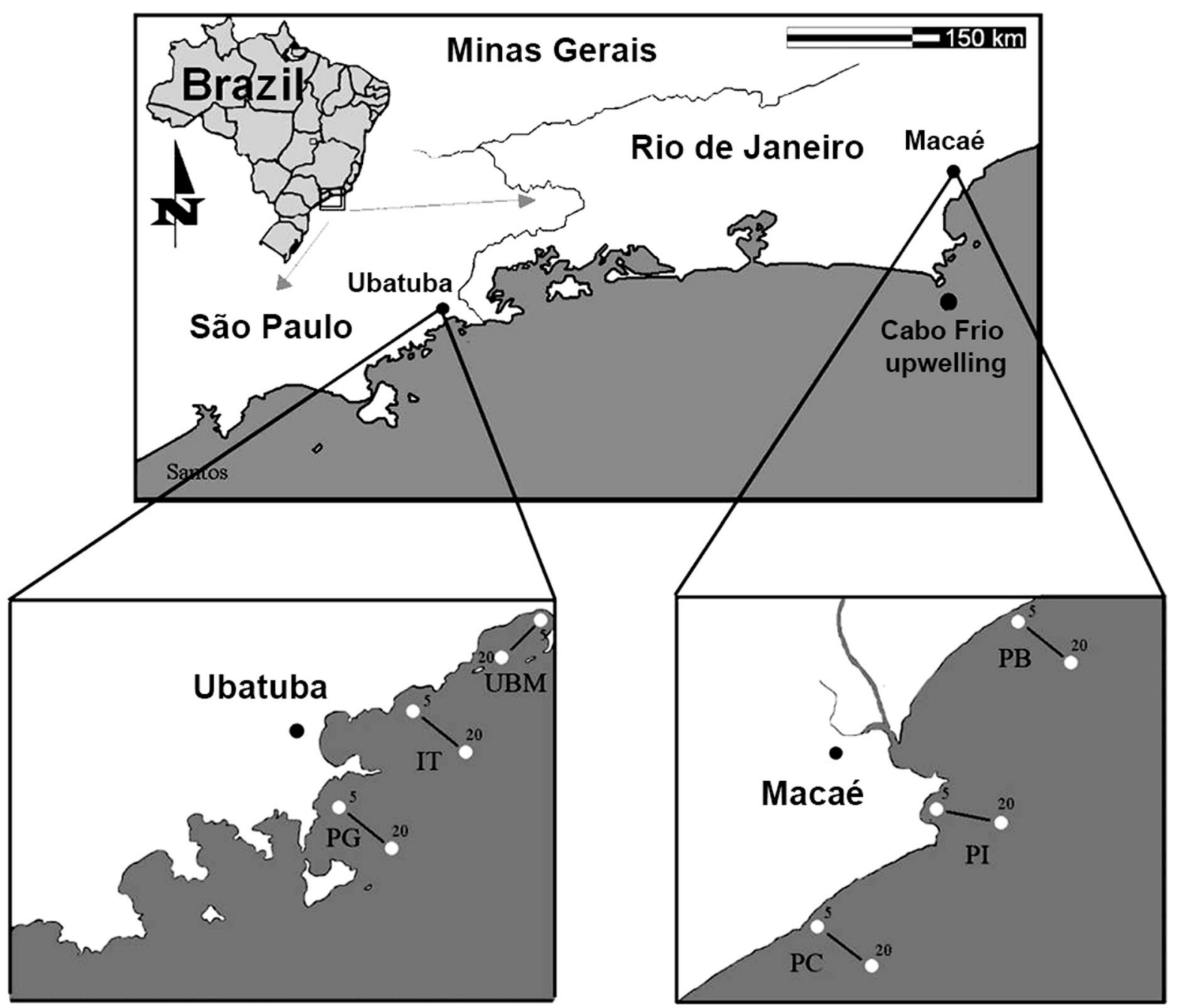

Fig. 1 Map indicating the sampling sites for each study location. $P B$ Barra Beach, $P I$ Imbetiba Beach, $P C$ Cavaleiros Beach, $U B M$ Ubatumirim, IT Itamambuca, $P G$ Praia Grande 
Environmental variables

The following measurements were taken (accuracy $=0.1$ ) at all sampling sites: bottom water temperature (BT) (digital thermometer, ${ }^{\circ} \mathrm{C}$ ) and bottom salinity (BS) (specific optical refractometer). Water samples were obtained using a Van Dorn bottle. Sediment samples were collected in each season for the analysis of the granulometric fraction (Phi) and organic matter $(\mathrm{OM})$, using a Van Veen grab (area: $0.06 \mathrm{~m}^{2}$ ). The sediment granulometric composition was expressed on the Phi scale $\left(=-\log _{2}\right.$ grain diameter, mm) (Tucker, 1988). For organic-matter analysis, sediment subsamples were incinerated at $500^{\circ} \mathrm{C}$ and then weighed again (Byers et al., 1978). Procedures related to granulometry and organic-matter content followed Costa et al. (2007).

Data analysis

Student's t test was used to test similarities $(P<0.05)$ in all environmental variables, by season (JanuaryMarch = summer; April-June = autumn; JulySeptember $=$ winter; October-December $=$ spring) and between the sampling locations.

The abundance (total number of individuals) was calculated for each season. The relative abundance was calculated for the entire sampling period (RA $=$ number of individuals of one species/total number of individuals of all species).

The Shannon-Wiener index (Pielou, 1966) was used to determine the assemblage diversity index $\left(H^{\prime}\right)$, species richness, and evenness $\left(J^{\prime}\right)$ in each season for each study location.

The original matrix was reduced for the multivariate analysis, eliminating the species present in less than 10\% of the samples (Cuesta et al., 2006; De Léo \& Pires-Vanin, 2006), that is, present in 4 trawls at least.

The cluster analysis was performed among species ( $\mathrm{R}$ mode) using the Bray-Curtis similarity index. The connection method used was UPGMA (UnweightedPair Group Averaging), which best reflects the original matrix affinities in the dendrogram (Krebs, 1989).

The relationship between species abundance and environmental factors was tested using the redundancy analysis (RDA) (Ter Braak, 1996). This analysis directly estimates the power of a relationship between two variable matrices. The first matrix is represented by environmental factors (temperature and salinity of the water, granulometry, and organic-matter content of the sediment) and the second is represented by all shrimp species, allowing the selection of environmental variables that best describe the distribution of species. This analysis was first conducted separately for each location, in order to identify environmental variables that affect the distribution of shrimp in each location. Then, the analysis was conducted for pooled data from the two locations.

\section{Results}

Environmental variables

Temperatures were lower $(P=0.001)$ and more homogeneous in all seasons in Macaé (Fig. 2) than in Ubatuba. Temperature in Macaé ranged from 19.50 to $22.91^{\circ} \mathrm{C}\left(21.97 \pm 1.21^{\circ} \mathrm{C}\right)$ and in Ubatuba from 20 to $28.83^{\circ} \mathrm{C}\left(23.7 \pm 2.84^{\circ} \mathrm{C}\right)$. Bottom salinities were also more homogeneous in Macaé, but were higher $(P<0.001)$ in all seasons (Fig. 2) compared to Ubatuba. The mean BS ranged from 35.66 to $38.0 \mathrm{ppt}(36.9 \pm 0.8 \mathrm{ppt})$ in Macaé and from 30.33 to $35.66 \mathrm{ppt}(33.5 \pm 1.8 \mathrm{ppt})$ in Ubatuba.

The organic-matter content of sediment was higher in Macaé $(P<0.001)$, ranging from 4.51 to $11.79 \%$ $(9.03 \pm 3: 48 \%)$, and in Ubatuba from 2.19 to $3.79 \%$ $(2.81 \pm 3.16 \%)$. The sediment in Macaé was composed predominantly of very fine sand, silt, and clay (with Phi values ranging from 3 to 5), and that in Ubatuba was composed mainly of fine and very fine sand (with Phi values ranging from 2 to 4). For the entire sampling period, Macaé had finer sediments (higher Phi values) $(P<0.001)$, composed mainly of silt and clay (4.22 \pm 0.84$)$; in Ubatuba the sediment was composed mainly of fine sand $(2.59 \pm 1.32)$ (Fig. 2).

Species composition and abundance

We estimated a total of 148,266 individuals $(102,832$ in Macaé and 45,434 in Ubatuba) captured, including 15 species and 13 genera, from 7 families: Penaeidae, Solenoceridae, and Sicyoniidae (superfamily Penaeoidea) and Palaemonidae, Alpheidae, Hippolytidae, and Lysmatidae (infraorder Caridea) (Table 1). Most species were collected in both locations, except for 
Fig. 2 Means, standard deviation, and minimum and maximum range of bottom temperature, bottom salinity, organic-matter content, and granulometry of sediments in Macaé and Ubatuba during the seasons
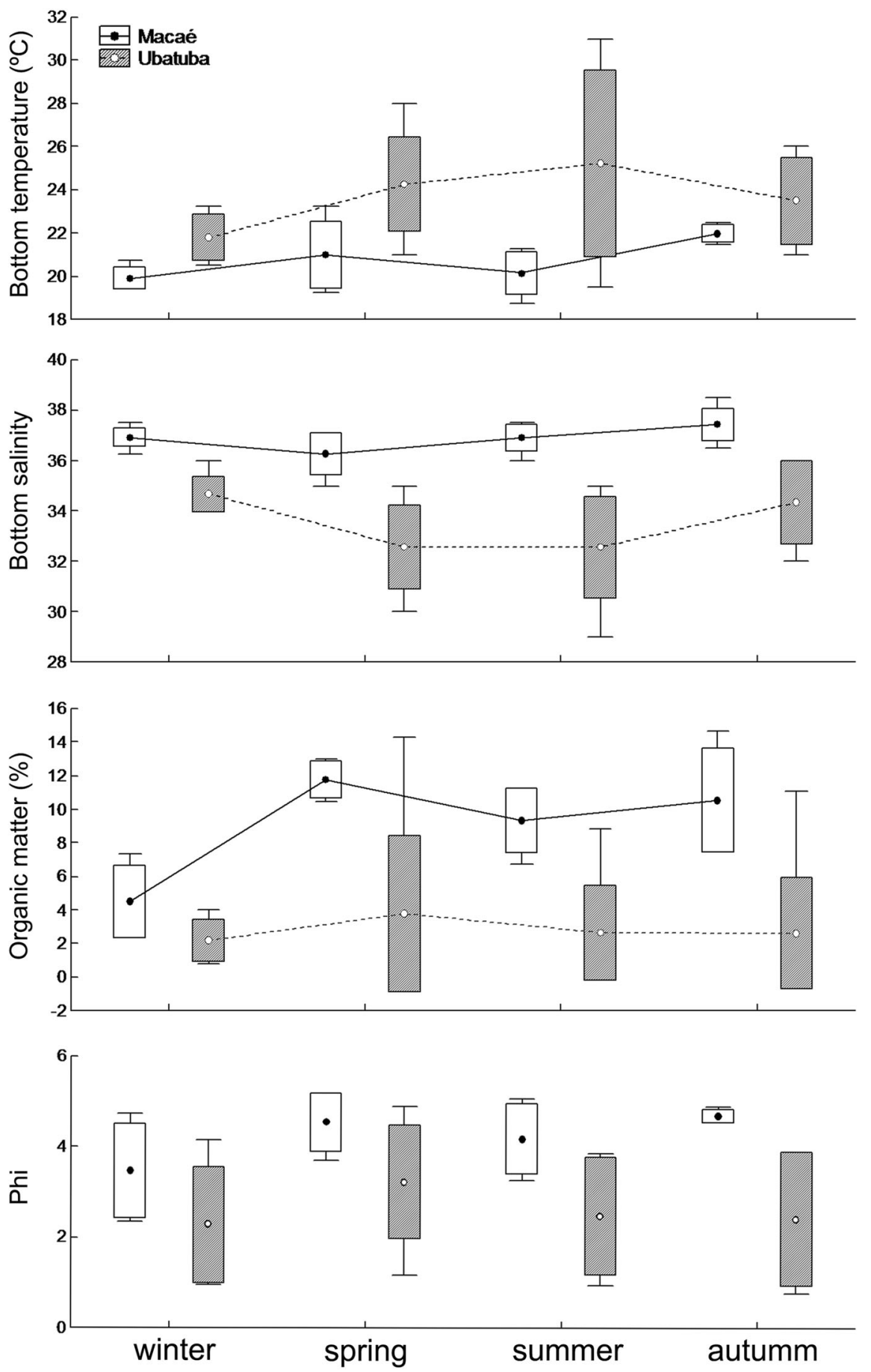

Sicyonia laevigata Stimpson, 1871, Periclimenes paivai Chace, 1969, and Lysmata sp., which were captured only in Macaé, and Leander paulensis Ortmann, 1897, captured only in Ubatuba.
The shrimp assemblage in Ubatuba was heavily dominated by $X$. kroyeri, which showed a relative abundance (RA) of $84.84 \%$ (Table 1). The second most abundant species in this location was 


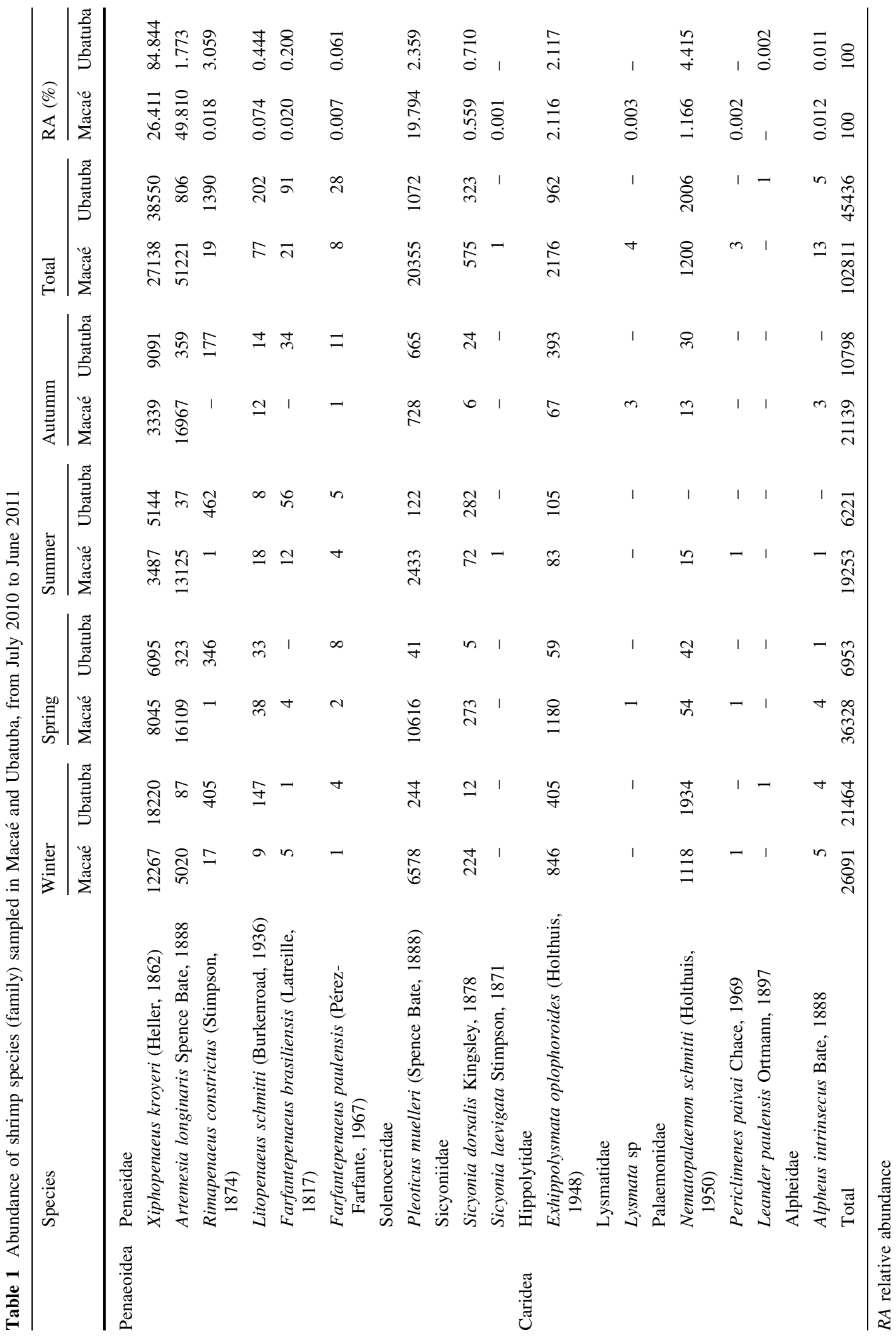


Nematopalaemon schmitti (Holthuis, 1950) $(R A=4.41 \%)$. In contrast, in Macaé, three penaeid species together comprised $96.01 \%$ of the total abundance: A. longinaris $(R A=49.81 \%), X$. kroyeri $(A R=26.41 \%)$, and $P$. muelleri $(R A=19.79 \%)$. The caridean with the highest abundance (absolute and relative) was Exhippolysmata oplophoroides (Holthuis, 1948) $(R A=2.11 \%)$ (Table 1).

The highest total shrimp abundance was recorded in Macaé $(35.32 \%)$ in spring, followed by winter (25.37\%) (Table 1). In Ubatuba, the highest total shrimp abundance occurred in winter (35.32\%), followed by autumn $(23.76 \%)$.

\section{Assemblage parameters}

During the study period, the richness was 15 species, including 14 in Macaé and 12 in Ubatuba. The number of species in both locations was equal (12) in winter and autumn (10). However, more species were caught in Macaé than in Ubatuba in the spring (13 and 10, respectively) and summer (13 and 9, respectively) (Fig. 3).

Macaé showed a higher diversity index and evenness $\left(H^{\prime}=1.19\right.$ and $\left.J^{\prime}=0.45\right)$ compared to Ubatuba $\left(H^{\prime}=0.70\right.$ and $\left.J^{\prime}=0.28\right)$. This was observed in all seasons, but the periods with higher values differed between locations. In Macaé, the highest values were observed in winter $\left(H^{\prime}=1.31\right.$ and $\left.J^{\prime}=0.53\right)$ and spring $\left(H^{\prime}=1.22\right.$ and $\left.J^{\prime}=0.47\right)$, while in Ubatuba higher values were recorded in the summer $\left(H^{\prime}=0.72\right.$ and $\left.J^{\prime}=0.32\right)$ and autumn $\left(H^{\prime}=0.68\right.$ and $\left.J^{\prime}=0.29\right)$ (Fig. 3).

\section{Multivariate analysis}

The Cluster analysis generated two groups in Macaé. The first group was composed of the more abundant species, with $40 \%$ similarity (Sicyonia dorsalis Kingsley, 1878, N. schmitti, E. oplophoroides, P. muelleri, $X$. kroyeri, and A. longinaris); the second one was composed of the less-abundant species [Litopenaeus schmitti (Burkenroad, 1936), Alpheus intrinsecus Bate, 1888, Farfantepenaeus paulensis (Pérez-Farfante, 1967), and $F$. brasiliensis (Latreille, 1817)] with $30 \%$ similarity. In Ubatuba, nearly all species formed a single group with a $10 \%$ similar distribution, except $X$. kroyeri, which remained separate from all other species.
If we consider the most abundant species ( $A$. longinaris, $X$. kroyeri, and $P$. muelleri), a group with $85 \%$ similarity was formed in Macaé, and A. longinaris and $X$. kroyeri were the closest to each other. In Ubatuba, A. longinaris and P. muelleri showed the greatest similarity among the species $(50 \%)$ and they were not related to $X$. kroyeri (Fig. 4).

When we analyzed each location separately, the RDA did not identify any significant environmental variable $(P<0.05)$. Therefore, we used the data matrix formed by the grouping of species and environmental variables of the two locations together.

The relationship between shrimp species abundance and environmental variables shown by RDA is represented by two axes (Table 2; Fig. 5). The first axis of the triplot graph explained $77 \%$ of the total variance of the data, while the second axis explained 17\%. With forward selection and Monte Carlo permutation tests (999 permutations), the RDA showed that all the environmental variables (BT, BS, $\mathrm{OM}$, and Phi) explained a significant amount $(P \leq 0.05)$ of the data variation, considering species abundance (explained variance $=0.95,0.99,-0.96$, and -0.95 , respectively).

According to the RDA, the abundance of $A$. longinaris, $P$. muelleri, L. schmitti, and the carideans $N$. schmitti and E. oplophoroides showed a directly proportional correlation with BS, OM, and Phi, while the abundances of $X$. kroyeri, $F$. paulensis, $F$. brasiliensis, and Rimapenaeus constrictus (Stimpson, 1874) correlated inversely with these variables. The bottom temperature (BT) showed a directly proportional correlation with the abundances of $X$. kroyeri, $F$. paulensis, F. brasiliensis, and $R$. constrictus.

\section{Discussion}

Environmental variables

Macaé is influenced by the SACW during most of the year, but more intensely during the spring and summer (Stech et al., 1995). Off Ubatuba, during the summer, the SACW also penetrates the bottom layer over the continental shelf, reaching the coastal area (PiresVanin \& Matsuura, 1993; Costa et al., 2007; Castilho et al., 2012). These authors explained that during winter in Ubatuba, the temperature distribution in the coastal zone becomes homogeneous with the 
Fig. 3 Means and standard deviation for localities and seasons, in relation to species richness, ShannonWiener diversity index $\left(H^{\prime}\right)$, and evenness $\left(J^{\prime}\right)$
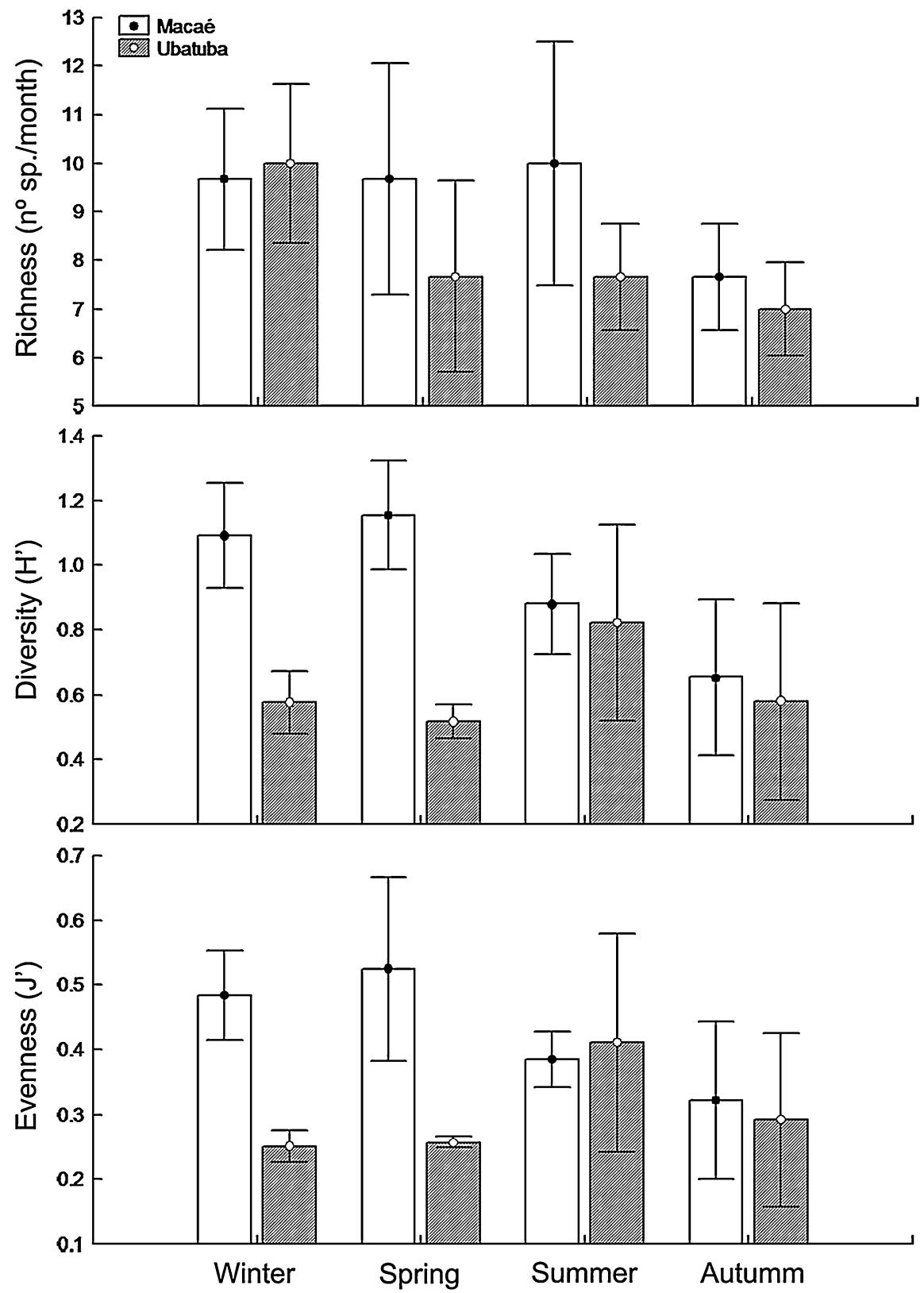

regression of the $\mathrm{SACW}$, and the entire location is covered with water between 20 and $25^{\circ} \mathrm{C}$. However, off Macaé, bottom temperatures lower than $20^{\circ} \mathrm{C}$ are observed, even in winter and autumn.

Larger amounts of $\mathrm{OM}$ in sediments of the upwelling location (Macaé) were also observed in studies comparing Cabo Frio and Ubatuba (Sumida et al., 2005; De Léo \& Pires-Vanin, 2006). This is probably a result of the higher primary productivity due to upwelling, since part of the OM generated is transferred to the benthos (Sumida et al., 2005). The amount of freshwater discharged by rivers onto the inner shelf at the upwelling location is scarce, and the nutrient enrichment depends on the pumping of the SACW from the slope (Acha et al., 2004).

The decrease in the mean BS in both locations, especially during the summer, can also be related to the influence of the SACW. Besides the decrease in temperature, salinities are also lower (Castro-Filho et al., 1987). Additionally, both locations have only 


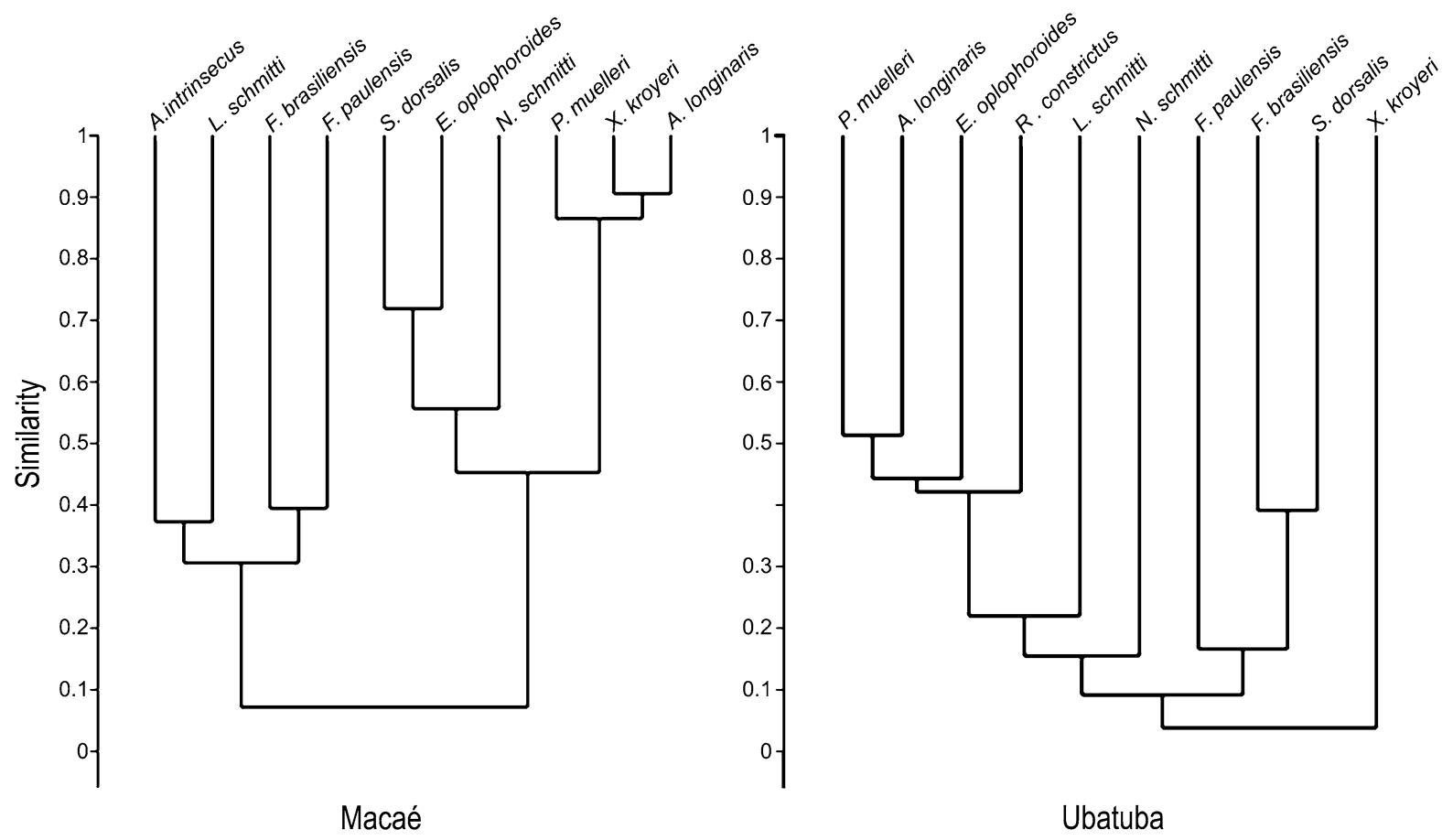

Fig. 4 Dendrogram obtained from cluster analysis (UPGMA, Bray-Curtis, R mode), showing the groups of shrimp species sampled in Macaé and Ubatuba for the study period

Table 2 Results of redundancy analysis (RDA) between the environmental variables and the abundance of shrimp species collected in Macaé and Ubatuba, from July 2010 through June 2011

\begin{tabular}{|c|c|c|c|c|}
\hline Environmental variables & Explained variance (RDA1) & Explained variance (RDA 2) & $r^{2}$ & $P$ \\
\hline Bottom temperature & 0.951 & -0.306 & 0.543 & $0.002 *$ \\
\hline Bottom salinity & -0.998 & -0.057 & 0.645 & $0.001 *$ \\
\hline Organic matter & -0.980 & -0.196 & 0.626 & $0.001 *$ \\
\hline Phi & -0.966 & -0.257 & 0.621 & $0.002 *$ \\
\hline
\end{tabular}

Proportion explained: RDA $1=76.88 \%$ and RDA $2=17.47 \%$

* Significant values $(P<0.005)$

small estuaries (Costa \& Fransozo, 1999; Acha et al., 2004). The highest fluctuations in salinity at Ubatuba may be related to differences of rainfall between locations. The average annual rainfall of Ubatuba is almost double of that recorded in Macaé (2552 and $1126 \mathrm{~mm}$, respectively) which may have influenced the observed values of salinity (rainfall data sourced from www.climatedata.org).

\section{Species composition and abundance}

This study characterized the richness and abundance of shrimp up to $20 \mathrm{~m}$ of unconsolidated substrate. The largest fishing effort in southeastern Brazil occurs at these depths, due to the presence of the seabob shrimp $X$. kroyeri, one of the main fisheries resources of the region (Costa et al., 2007; Heckler et al., 2014). Considering the shallow depths sampled in this study, the fauna of penaeoid shrimps caught in both locations was well represented. Off Ubatuba, we caught 8 of the 15 species recorded for the coast of São Paulo state (Costa et al., 2000; De Léo \& Pires-Vanin, 2006). Off Macaé, we caught 9 of the 17 species listed along the coast of Rio de Janeiro state (D'Incao, 1995). In the present study, six species considered target of artisanal and industrial trawls in southeastern coast of Brazil were recorded (A. longinaris, P. muelleri, X. kroyeri, $F$. paulensis, F. brasiliensis, and L. schmitti). 


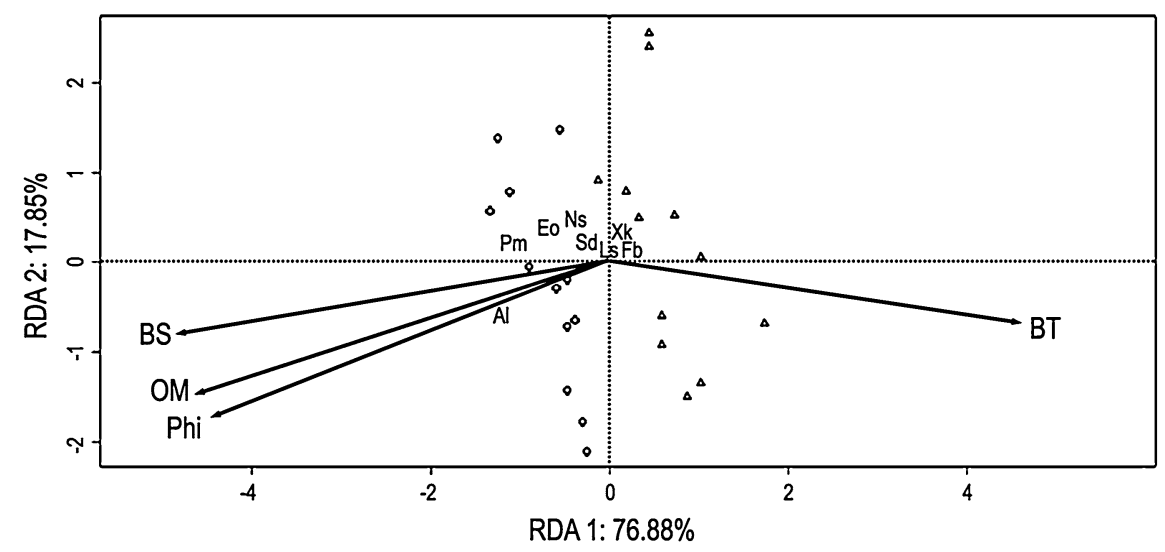

Fig. 5 Triplots from the redundancy analysis (RDA) illustrating the relationship between the significant environmental variables $(P \leq 0.05)$ and abundance of shrimp species sampled in Macaé and Ubatuba, from July 2010 through June 2011. BT bottom temperature, $B S$ bottom salinity, $O M$ organic-matter content; Xk Xiphopenaeus kroyeri; Pm Pleoticus muelleri; Al

Some species of deeper regions were not found during our survey, e.g. Parapenaeus americanus Rathbun, 1901, usually found at depths of 50 to 70 m (Costa et al. 2000; De Léo \& Pires-Vanin 2006). Records of other species as Solenocera necopina Burkenroad, 1939, S. atlantidis Burkenroad, 1939, and Mesopenaeus tropicalis (Bouvier, 1905) were considered atypical at Ubatuba (Pires, 1992), and yet Sicyonia parri (Burkenroad, 1934) can be considered rare (Nakagaki et al., 1995; Costa et al., 2000) and were not found in recent works (Furlan et al., 2013) as well as in the present survey.

The present results showed greater shrimp abundances at Macaé (102,832 in Macaé and 45,434 in Ubatuba). Comparisons about the amount of shrimp fishing boats between locations are not possible due to lack of reliable and standardized estimates. Boats from other regions of Brazil often come to these locations, making it even more difficult to compare the fishing effort between Macaé and Ubatuba. Penaeid fisheries occur on the entire Brazilian coast, but Rio de Janeiro State has the highest fishery productivity of this region (IBAMA, 2007). Regardless of this increased production occurs due to a possible large fishing effort; in the present study, most shrimps were collected at Macaé in the same way, indicating that this greatest abundance is not a fishing effect.

Periclimenes paivai was recorded for the first time off the coast of Rio de Janeiro, which expands its known geographical distribution. According to
Artemesia longinaris, Sd Sicyonia dorsalis, Fb Farfantepenaeus brasiliensis, Fp Farfantepenaeus paulensis, Ls Litopenaeus schmitti, Rc Rimapenaeus constrictus; Eo Exhippolysmata oplophoroides, Ns Nematopalaemon schmitti. Triangle and circle correspond to the months of sampling in Macaé and Ubatuba, respectively

Ramos-Porto \& Coelho (1998), this caridean occurred between the states of Santa Catarina and São Paulo. In general, shrimps of the genus Periclimenes Costa, 1844 are commonly found associated with benthic hosts. However, P. paivai was, until now, the only one among Brazilian species of the genus found on scyphozoan hosts (Martinelli-Filho et al., 2008). The aforementioned authors studied the shrimp associated with two scyphomedusae: Lychnorhiza lucerna Haeckel, 1880 and Chrysaora lactea Eschscholtz, 1829, both species distributed over the entire Brazilian coastline (Morandini et al., 2006). This fact enables the species occurring in northern regions of Rio de Janeiro, although it has not yet been registered.

The high abundance of $A$. longinaris and $P$. muelleri off Macaé compared to Ubatuba could be considered atypical, considering the tropical position of the location. These two species are subantarctic and hence indicative of the presence of cold water (Boschi, 1969, 1986; Gavio \& Boschi, 2004; Fransozo et al., 2004; Costa et al., 2004, 2005). Both species are abundant in Argentina, where they are commercially important and represent the main components of the coastal marine food chains, as they are intensively predated by fishes (Boschi, 1963, 1969, 1986). Off the coast of São Paulo state, these two shrimps are captured mainly during SACW intrusions (Costa et al., 2005; Castilho et al., 2008; Carvalho-Batista et al., 2011). However, off Macaé, these species were 
present in great abundance during all months of the study. This can be related with temperature conditions in this location (mean $=20.7^{\circ} \mathrm{C}$ ), which are very similar to areas at higher latitudes and likely allow the two species to remain in Macaé coast throughout the year.

Sancinetti et al. (2014) hypothesized that a population of A. longinaris has become established on the northern coast of Rio de Janeiro state, which is possible due to the environmental conditions (low temperatures) and considering that individuals of this population migrate with the SACW to higher-latitude locations, such as Ubatuba. This may actually be the case, since genetic analyses performed on this species in the same locations confirmed the existence of gene flow (Carvalho-Batista et al., 2014). This hypothesis could also be applied to $P$. muelleri. However, despite being collected throughout the year, the abundance of $P$. muelleri fluctuated more widely than that of $A$. longinaris during the study in Macaé, with peaks in winter and spring, whereas the abundance of $A$. longinaris was more uniform throughout the year. This finding concords with the observations of Costa et al. (2005), who suggested that A. longinaris is more eurythermal and tolerates higher temperature ranges compared to $P$. muelleri.

Artemesia longinaris has continuous recruitment off Macaé coast (Sancinetti et al., 2015). On the other hand, Castilho et al. (2007), in a 5.5-year study in Ubatuba, found juveniles in low numbers during almost all months over the entire study period and interpreted recruitment as episodic, since there was no apparent correlation between the percentages of mature females and immature individuals. These results suggest that most of variations observed in abundance of A. longinaris in Macaé may be related to juvenile recruitment. Additionally, the upwelling greatly increases the primary production (Odebrecht \& Castello, 2001; Gaeta \& Brandini, 2006), so it is possible to hypothesize that Macaé has nursery function, not only for A. longinaris but also for other species. Studies investigating the juvenile recruitment of other species at this location are needed to clarify this hypothesis.

The highest abundance of $X$. kroyeri in the study period was observed in winter for both locations, which was similar to other studies (Fransozo et al., 2002; Castro et al., 2005; Costa et al., 2007). The high abundance in winter may have been influenced by the reduction of fishing pressure during the annual closed season (IBAMA, 2008), from March through May, comprising most of the autumn.

Among the caridean shrimps sampled in this study, E. oplophoroides and $N$. schmitti were the most abundant species. The observed abundances were reversed, i.e., in Macaé (colder location) we collected more individuals of E. oplophoroides than those of $N$. schmitti, while in Ubatuba the opposite occurred. It is possible that $N$. schmitti is less tolerant to cold temperatures than E. oplophoroides. On the other hand, Fransozo et al. (2005, 2009) studied the distribution of these caridean shrimps in Ubatuba Bay and suggested that marine biogenic debris and land-derived material (shells, sticks, leaves, etc.) might be the key to explain the patchy distribution of these and other caridean shrimps. The biomass of land-derived bio-detritus might provide protection against predators as it creates environmental heterogeneity in soft-bottom habitats (Fransozo et al., 2009). However, no estimation of debris biomass was recorded by us.

\section{Assemblage parameters}

The two locations showed no great contrast in the number of species (14 in Macaé and 12 in Ubatuba). Similarly, De Léo \& Pires-Vanin (2006) recorded 38 and 37 species (Cabo Frio and Ubatuba, respectively) when sampling the entire benthic megafauna deeper than $40 \mathrm{~m}$. The greatest difference in species richness was observed in spring and summer, where Macaé showed a larger number of species. However, the presence of some species in low abundance, sometimes with only one individual collected (for example S. laevigata), provided this result. Although S. laevigata and P. paivai were captured in Macaé and not in Ubatuba in this study, both species have been recorded for this location (Ramos-Porto \& Coelho, 1998; Costa et al., 2000).

The diversity gradients are associated with several environmental variables, such as depth, temperature, OM (Cartes et al., 2008), sediment type, and dissolved oxygen content (Dickinson, 1978), which influence the distribution and richness of the species. In assemblages at great depths, abundance peaks have been related to areas of high primary productivity (Billett et al., 2001; Ruhl \& Smith, 2004; Cartes et al., 2009). Besides zooplankton, primary productivity 
may also influence the distribution of benthic organisms: the relatively high zooplankton productivity resulting from this higher primary productivity transfers energy to the benthic compartments, mainly through fecal pellets and dead organisms (GonzalezRodriguez et al., 1992; Valentin \& Monteiro-Ribas, 1993).

These above-mentioned factors may have influenced the higher diversity in Macaé, considering the increased primary productivity in the location, the finer sediments rich in OM, and favorable temperatures for some abundant species (A. longinaris and $P$. muelleri, for example). This relatively high diversity can be ascribed mainly to the local environmental factors, more than the actual latitudinal differences. In marine environments, the influence of latitude on diversity is less marked than in the terrestrial environment (Rex et al., 2000), and the latitudinal difference between these two studied locations is less than $1^{\circ}$.

The constant occurrence of $A$. longinaris and $P$. muelleri in Macaé considerably increased the diversity index, considering that in addition to species richness, this index also considers abundance and evenness. In contrast, the lower index at Ubatuba occurred due to the high relative abundance of $X$. kroyeri, which comprised over $85 \%$ of the total shrimp collected in the location. Changes in the diversity index in both locations were affected mainly by the most abundant species (A. longinaris, X. kroyeri, and P. muelleri). The higher values coincide with the periods when these species had even temporal distributions.

\section{Multivariate analysis}

The distributions of the most abundant species (A. longinaris, $X$. kroyeri, and $P$. muelleri) were highly similar in Macaé, but not in Ubatuba. This is probably related to the environmental conditions, mainly the range of bottom temperature, allowing the three species to remain in Macaé year-round. For Ubatuba, A. longinaris and P. muelleri are found only in periods when the influence of low temperature is greater (Costa et al., 2004, 2005), and X. kroyeri inhabits the location year-round (Costa et al., 2007; Fransozo et al., 2002; Castro et al., 2005). For these reasons, these three species showed low similarity in Ubatuba. This is reinforced by the results obtained in the RDA, showing a preference for lower temperatures of $A$. longinaris and P. muelleri and the opposite for $X$. kroyeri.

The main variables that affect the distribution of $X$. kroyeri in Ubatuba are the sediment type, salinity, and temperature, with high abundance of the species in areas characterized by muddy substrates and high salinity and temperature (Costa et al., 2007). In the present observations, those characteristics showed strong correlations with the abundance of this species (RDA). However, the analysis showed an inverse correlation between the abundance of X. kroyeri and salinity values, as well as phi values. This result of RDA can be explained by the ranges of the parameters observed in each location and the fact that more individuals of the species were captured in Ubatuba. Costa et al. (2007) observed higher abundances in salinities of 36-38 ppt. In the present study, the mean salinity in Macaé was $36.9 \mathrm{ppt}$, while in Ubatuba was $33.5 \mathrm{ppt}$. The same happened with phi values, since the species prefers values of 3-7 (Costa et al., 2007), and the mean phi observed in Macaé was 4:22, while in Ubatuba was 2.59 .

For marine benthic species, distribution and abundance are limited mainly by the temperature, salinity, depth, texture of the sediment, and OM (Furlan et al., 2013). These environmental variables have provided a significant amount of explanation for the distribution of the species (RDA), but it must be noted that a number of other environment features can influence the distribution of these organisms. The presence of heterogeneous substrate containing macroalgae, seagrass meadows, coral reefs, and hydroids represents an important feature in the environment for the presence of shrimps (Bauer, 1985a, b; Costa et al., 2000; Macia et al., 2004). Many caridean species occur on microhabitats associated to the rocky shallow subtidal (Costa et al., 2000). However, the areas sampled in both studied locations are composed only of unconsolidated substrate with sandy or muddy sediments.

In the present study, both sampled locations comprised some species of tropical and subantarctic origin in the southwestern Atlantic Ocean. Despite the fact that sampled assemblages did not show great differences in richness and composition, it was possible to detect marked differences in the abundance of the species. In Macaé, we recorded great abundances of species with subtropical affinity (A. longinaris and $P$. muelleri), while in Ubatuba a tropicalrelated species (X. kroyeri) was the dominant species, 
resulting in greater values in the diversity indices for Macaé. Water temperature and sediment offered the most convincing explanation for the differences among the abundance patterns of species. However, it is important to take into account that other factors such as intraspecific migrations, competition, and predation may also influence this result. The present study provides important findings for supporting conservation actions, which should be distinct for each location, since in Macaé two species of economic interest are found in great abundances, often larger than those of $X$. kroyeri, the main exploited species in the state of São Paulo.

Acknowledgements Support for this study was provided by Grants from the Fundação de Amparo à Pesquisa do Estado de São Paulo-FAPESP (AR: \#2009/54672-4, Biota Temático 2010/50188-8) and the Conselho Nacional de Desenvolvimento Científico e Tecnológico-CNPq to RCC (305919/2014-8). JAFP thanks CNPq for a Master's of Science scholarship (130837/2011-3). Thanks are due to all members of the LABCAM and NEBECC and to Dr. Alexandre Azevedo and Dr. Gustavo Sérgio Sancinetti for their help during fieldwork; and to Dr. Maria Lúcia Negreiros Fransozo for her extremely constructive comments on an earlier version of this manuscript. We also thank the Universidade Federal do Rio de Janeiro/ NUPEM for providing infrastructure to carry out this work at Macaé, and the Instituto Chico Mendes de Biodiversidade/ ICMBio for granting permission to collect the shrimp (SISBIO No. 23012-1).

\section{References}

Ab'Sáber, A. N., 1955. Contribuição à geomorfologia do litoral paulista. Revista Brasileira de Geografia 17: 3-37.

Acha, E. M., H. W. Mianzan, R. A. Guerrero, M. Favero \& J. Bava, 2004. Marine fronts at the continental shelves of austral South America physical and ecological processes. Journal of Marine Systems 44: 83-105.

Bakun, A. \& R. H. Parrish, 1990. Comparative studies of coastal pelagic fish reproductive habitats: the Brazilian sardine (Sardinella aurita). Journal du Conseil International pour l' Exploration de la Mer 46: 269-283.

Bauer, R. T., 1985a. Diel and seasonal variation in species composition and abundance of caridean shrimps (Crustacea, Decapoda) from Seagrass meadows on the north coast of Puerto Rico. Bulletin Marine Science 36: 150-162.

Bauer, R. T., 1985b. Penaeid shrimp fauna from tropical seagrass meadows-species composition, diurnal, and seasonal-variation in abundance. Proceedings of the Biological Society of Washington 98: 177-190.

Billett, D. S. M., B. J. Bett, A. L. Rice, M. H. Thurston, J. Galéron, M. Sibuet \& G. A. Wolff, 2001. Long-term change in the megabenthos of the Porcupine Abyssal Plain (NE Atlantic). Progress in Oceanography 50: 325-348.
Boschi, E. E., 1963. Los camaronês comerciales de La familia Penaeidae de la costa Atlántica de América Del Sur. Boletim do Instituto de Biologia Marinha 3: 1-39.

Boschi, E. E., 1969. Estudio biológico pesquero Del camarón Artemesia longinaris Bate de Mar del Plata. Boletim del Instituto Nacional de Investigación y Desarrollo Pesquero Mar del Plata 18: 1-47.

Boschi, E. E., 1986. La pesquería Del langostino del litoral patagónico. Revista Redes 20: 1-8.

Branco, J. O., 2005. Fishery and biology of the sea-bob-shrimp Xiphopenaeus kroyeri (Heller) (Crustacea, Penaeldae), at Armação do Itapocoroy, Penha, Santa Catarina, Brazil. Zoologia 22: 1050-1062.

Bugoni, L. \& C. M. Vooren, 2004. Feeding ecology of the Common Tern Sterna hirundo in a wintering area in southern Brazil. Ibis 146: 438-453.

Byers, S. C., E. L. Mills \& P. L. Stewart, 1978. A Comparison of methods of determining organic carbon in marine sediments, with suggestions for a standard method. Hydrobiologia 58: 43-47.

Cartes, J. E., T. Madurell, E. Fanelli \& J. L. López-Jurado, 2008. Dynamics of suprabenthos zooplankton communities around the Balearic Islands (western Mediterranean): Influence of environmental variables and effects on the biological cycle of Aristeus antennatus. Journal of Marine Systems 71: 316-335.

Cartes, J. E., F. Maynou, E. Fanelli, C. Romano, V. Mamouridis \& V. Papiol, 2009. The distribution of megabenthic, invertebrate epifauna in the Balearic Basin (Western Mediterranean) between 400 and 2300 m: environmental gradients influencing assemblages' composition and biomass trends. Journal of Sea Research 61: 244-257.

Carvalho-Batista, A., M. Negri, L. G. Pileggi, A. L. Castilho, R. C. Costa \& F. L. Mantelatto, 2014. Inferring population connectivity across the range of distribution of the stiletto shrimp Artemesia longinaris Spence Bate, 1888 (Decapoda, Penaeidae) from DNA barcoding: implications for fishery management. Zookeys 457: 271-288.

Carvalho-Batista, A., S. M. Simões, M. Lopes \& R. C. Costa, 2011. Ecological distribution of the shrimp Pleoticus muelleri (Bate, 1888) and Artemesia longinaris Bate, 1888 (Decapoda: Penaeoidea) in the Southeastern Brazilian littoral. Nauplius 19: 135-143.

Castilho, A. L., R. C. Costa, A. Fransozo \& E. E. Boschi, 2007. Reproductive pattern of the South American endemic shrimp Artemesia longinaris (Decapoda, Penaeidae), off the coast of São Paulo state, Brazil. Revista de Biologia Tropical 55: 39-48.

Castilho, A. L., M. R. Pie, A. Fransozo, A. P. Pinheiro \& R. C. Costa, 2008. The relationship between environmental variation and species abundance in shrimp community (Crustacea: Decapoda: Penaeoidea) in southeastern Brazil. Journal of the Marine Biological Association of the United Kingdom 88: 119-123.

Castilho, A. L., M. R. Wolf, S. M. Simões, G. L. Bochini, V. Fransozo \& R. C. Costa, 2012. Growth and reproductive dynamics of the South American red shrimp, Pleoticus muelleri (Crustacea: Solenoceridae), from the southeastern coast of Brazil. Journal of Marine Systems 105: 135-144.

Castro, R. H., R. C. Costa, A. Fransozo \& F. L. Mantelatto, 2005. Population structure of the seabob shrimp 
Xiphopenaeus kroyeri (Heller, 1862) (Crustacea: Penaeoidea) in the littoral of São Paulo, Brazil. Scientia Marina 69: 105-112.

Castro-Filho, B. M., L. B. Miranda \& S. Y. Myao, 1987. Condições hidrográficas na plataforma continental ao largo de Ubatuba: variações sazonais e em média escala. Boletim do Instituto Oceanográfico 35: 135-151.

Castro-Filho, B. M. \& L. B. Miranda, 1998. Physical oceanography of the western Atlantic continental shelf located between $4^{\circ} \mathrm{N}$ and $34^{\circ} \mathrm{S}$ coastal segment $\left(4^{\circ} \mathrm{W}\right)$. In Robinson, A. R. \& K. H. Brink (eds.), The Sea. Wiley, New York: 209-251.

Coelho-Souza, S. A., M. S. López \& J. R. D. Guimarães, 2012. Biophysical interactions in the Cabo Frio upwelling system, Southeastern Brazil. Brazilian Journal of Oceanography 60: 353-365.

Costa, R. C. \& A. Fransozo, 1999. A nursery ground for two tropical pink-shrimp Penaeus species: Ubatuba Bay, northern coast of São Paulo, Brazil. Nauplius 7: 73-81.

Costa, R. C., A. Fransozo, F. L. Mantelatto \& R. H. Castro, 2000. Occurrence of shrimp species (Natantia: Penaeidea: Caridea) in Ubatuba Bay, Ubatuba, SP, Brazil. Proceedings of the Biological Society of Washington 113: 776-781.

Costa, R. C., A. Fransozo \& A. P. Pinheiro, 2004. Ecological distribution of the shrimp Pleoticus muelleri (Bate, 1888) (Decapoda: Penaeoidea) in southeastern Brazil. Hydrobiologia 529: 195-203.

Costa, R. C., A. Fransozo, A. L. Castilho \& F. A. M. Freire, 2005. Annual, seasonal and spatial variation of abundance of the shrimp Artemesia longinaris (Decapoda; Penaeoidea) in southeastern Brazil. Journal of the Marine Biological Association of the United Kingdom 85: 107-112.

Costa, R. C., A. Fransozo, F. A. M. Freire \& A. L. Castilho, 2007. Abundance and Ecological distribution of the "setebarbas" shrimp Xiphopenaeus kroyeri (Heller, 1862) (Decapoda: Penaeoidea) in three bays of the Ubatuba region, southeastern Brazil. Gulf and Caribbean Research 19: 33-41.

Cuesta, J. A., E. González-Ortegón, A. Rodríguez, F. Baldó, C. Vilas \& P. Drake, 2006. The decapod crustacean community of the Guadalquivir Estuary (SW Spain): seasonal and inter-year changes in community structure. Hydrobiologia 557: 85-95.

Cury, P., A. Bakun, R. J. M. Crawford, A. Jarre, R. A. Quiñones, L. J. Shannon \& H. M. Verheye, 2000. Small pelagics in upwelling systems: patterns of interaction and structural changes in "wasp-waist" ecosystems. ICES Journal of Marine Science 57: 603-618.

Dall, W., B. J. Hill, P. C. Rothlisberg \& D. J. Staples, 1990. The biology of the Penaeidae. In Blaxter, J. H. S. \& A. J. Southward (eds.), Advances in Marine Biology. Academic Press, San Diego: 489.

De Léo, F. C. \& A. M. S. Pires-Vanin, 2006. Benthic megafauna communities under the influence of the South Atlantic Central Water intrusion onto the Brazilian SE shelf: A comparison between an upwelling and a non-upwelling ecosystem. Journal of Marine Systems 60: 268-284.

Dickinson, J. J., 1978. Faunal comparison of the Gammarid Amphipoda (Crustacea) in two bathyal basins of the California continental borderland. Marine Biology 48: 367-372.
D’Incao, F., 1995. Taxonomia, padrões distribucionais e ecológicos de Dendrobranchiata (Crustacea: Decapoda) do litoral brasileiro. Doctoral thesis, Universidade Federal do Paraná, Curitiba; 365.

Franchito, S. H., T. O. Oda, V. B. Rao \& M. T. Kayano, 2008. Interaction between coastal upwelling and local winds at Cabo Frio, Brazil: an observational study. Journal of Applied Meteorology and Climatology 47: 1590-1598.

Fransozo, A., R. C. Costa, F. L. Mantelatto, M. A. A. Pinheiro \& S. Santos, 2002. Composition and abundance of shrimp species (Penaeidea and Caridea) in Fortaleza Bay, Ubatuba, São Paulo, Brazil. Modern Approaches to the Study of Crustacea: 117-123.

Fransozo, A., R. C. Costa, A. L. Castilho \& F. L. Mantelatto, 2004. Ecological distribution of the shrimp "camarão serrinha" Artemesia longinaris (Decapoda, Penaeidae) in Fortaleza Bay, Ubatuba, Brazil, in relation to abiotic factors. Revista de Investigación y Desarrollo Pesquero 16: 43-50.

Fransozo, V., R. C. Costa, G. Bertini \& V. J. Cobo, 2005. Population biology of spine shrimp Exhippolysmata oplophoroides (Holthuis) (Caridea, Hippolytidae) in a subtropical region, São Paulo, Brazil. Zoologia 22: 1078-1084.

Fransozo, V., A. L. Castilho, F. A. M. Freire, M. Furlan, A. C. Almeida, G. M. Teixeira \& J. A. Baeza, 2009. Spatial and temporal distribution of the shrimp Nematopalaemon schmitti (Decapoda: Caridea: Palaemonidae) at a subtropical enclosed bay in South America. Journal of the Marine Biological Association of the United Kingdom 89: 1581-1587.

Furlan, M., A. L. Castilho, L. C. Fernandes-Góes, V. Fransozo, G. Bertini \& R. C. Costa, 2013. Effect of environmental factors on the abundance of decapod crustaceans from soft bottoms off southeastern Brazil. Annals of the Brazilian Academy of Sciences 85: 1345-1356.

Gaeta, S. A. \& F. P. Brandini, 2006. Produção primária do fitoplâncton na região entre o Cabo de São Tomé (RJ) e o Chuí (RS). In Rossi-Wongtschowski, C. L. \& M. S. P. Madureira (eds.), O Ambiente Oceanográfico da Plataforma Continental e do Talude na área Sudeste-Sul do Brasil. São Paulo, EDUSP: 219-264.

Gavio, M. A. \& E. E. Boschi, 2004. Biology of the shrimp Artemesia longinaris Bate, 1888 (Crustacea: Decapoda: Penaeidae) from Mar del Plata coast, Argentina. Nauplius 12: 83-94.

Gonzalez-Rodriguez, E., J. L. Valentin, D. L. André \& S. A. Jacob, 1992. Upwelling and downwelling at Cabo Frio (Brazil): Comparison of biomass and primary production responses. Journal of Plankton Research 14: 289-306.

Haimovici, M., A. O. A. Silva, L. V. Miranda \& S. Klippel, 2007. Prospecção na região sudeste-sul. In Haimovici, M. (Org.), A prospecção pesqueira e abundância dos estoques marinhos no Brasil nas décadas de 1960 a 1990: levantamento de dados e avaliação crítica. Programa Revizee: Levantamento de Dados Pretéritos

Heckler, G. S., R. C. Costa, A. Fransozo, S. Rosso \& R. M. Shimizu, 2014. Long-term patterns of spatial and temporal distribution in the Seabob shrimp Xiphopenaeus kroyeri (decapoda: penaeidae) population in southeastern Brazil. Journal of Crustacean Biology 34: 326-333. 
IBAMA, 2007. Estatística da Pesca 2005 Brasil - Grandes Regiões e Unidades da Federação, 108. Brasília: IBAMA.

IBAMA, 2008. Instrução Normativa $\mathrm{N}^{\circ} 189$, de 23 de setembro de 2008. Reunião final com representações das regiões sudeste e sul, ocorrida em Itajaí/SC, no dia 21 de agosto de 2008; Processo IBAMA/SC no 2026.001828/2005-35.

Kaiser, M. J. \& B. E. Spencer, 1996. The effects of Beam-Trawl disturbance on infaunal communities in different habitats. Journal of Animal Ecology 65: 348-358.

Krebs, C. L., 1989. Ecological Methodology. Benjamin/Cummings, New York: 620.

Lehmann, A. \& K. Myrberg, 2008. Upwelling in the Baltic Sea-a review. Journal of Marine Systems 74: 3-12.

Macia, A., 2004. Juvenile penaeid shrimp density, spatial distribution and size composition in four adjacent habitats within a Mangrove-Fringed Bay on Inhaca Island, Mozambique. Western Indian Ocean Journal of Marine Science 3: 163-178.

Mahiques, M. M., 1995. Dinâmica sedimentar atual nas enseadas da região de Ubatuba, Estado de São Paulo. Boletim do Instituto Oceanográfico 43: 111-122.

Mann, K. H. \& J. R. R. Lazier, 1996. Dynamics of marine ecosystems: biological-physical interactions in the oceans, 2nd ed. Blackwell Science Limited, Oxford: 394.

Martinelli-Filho, J. E., S. N. Stam Par, A. C. Morandini \& E. C. Mossolin, 2008. Cleaner Shrimp (Caridea: Palaemonidae) associated with scyphozoan jellyfish. Vie et Milieu-Life and Environment 58: 133-140.

Merino, M. \& M. A. Monreal-Gómez, 2009. Ocean currents and their impact on marine life. In C. M. Duarte and A. L. Helgueral (eds), Marine Ecology. Encyclopedia of Life Support Systems (EOLSS), Developed under the Auspices of the UNESCO, Eolss Publishers, Oxford 1:52-47.

Morandini, A. C., M. O. Soares, H. Matthews-Cascon \& A. C. Marques, 2006. A survey of the Scyphozoa and Cubozoa (Cnidaria, Medusozoa) from the Ceará coast (NE Brazil). Biota Neotropica 6: 1-8.

Nakagaki, J. M., M. L. Negreiros-Fransozo \& A. Fransozo, 1995. Composição e abundância de camarões marinhos (Crustacea: Decapoda: Penaeidae) na Enseada de Ubatuba, Ubatuba, Brasil. Arquivos de Biologia e Tecnologia 38: 583-591.

Odebrecht, C. \& J. P. Castello, 2001. The convergence ecosystem in the southwest Atlantic. In Seeliger, U. \& B. Kjerfve (eds), Ecological Studies. Costal Marine Ecosystem of Latin America. 144 vol. Springer, Berlin: 360

Pauly, D., V. Christensen, S. Guénette, T. J. Pitcher, U. R. Sumaila, C. J. Walters, R. Watson \& D. Zeller, 2002. Towards sustainability in world fisheries. Nature 418: 689-695.

Pielou, E. C., 1966. The measurement of diversity in different types of biological collections. Journal of Theoretical Biology 13: 131-144.

Pires, A. M. S., 1992. Structure and dynamics of benthic megafauna on the continental shelf offshore of Ubatuba, southeastern, Brazil. Marine Ecology Progress Series 86: 63-76.
Pires-Vanin, A. M. S. \& Y. Matsuura, 1993. Estrutura e função do ecossistema de plataforma continental da região de Ubatuba, Estado de São Paulo: uma introdução. Boletim do Instituto Oceanográfico 10: 1-8.

Ramos-Porto, M. \& P. A. Coelho, 1998. Malacostraca. Eucarida. Caridea (Alpheoidea excluded). In Young, P. S. (eds), Catalogue of Crustacea of Brazil. Museu Nacional, Rio de Janeiro: 325-350.

Rex, M. A., C. T. Stuart \& G. Coyne, 2000. Latitudinal gradients of species richness in the deep-sea benthos of the North Atlantic. Proceedings of the National Academy of Sciences of the USA 97: 4082-4085.

Ruhl, H. A. \& K. L. Smith Jr, 2004. Shifts in deep-sea community structure linked to climate and food supply. Science 305: 513-515.

Sancinetti, G. S., A. Azevedo, A. L. Castilho, A. Fransozo \& R. C. Costa, 2014. How marine upwelling influences the distribution of Artemesia longinaris (Decapoda: Penaeoidea) Latin American. Journal of Aquatic Research 42: 322-331.

Sancinetti, G. S., A. Azevedo, A. L. Castilho, A. Fransozo \& R. C. Costa, 2015. Population biology of the commercially exploited shrimp Artemesia longinaris (Decapoda: Penaeidae) in an upwelling region in the Western Atlantic: comparisons at different latitudes. Brazilian Journal of Biology 75: 305-313.

Stech, J. L., J. A. Lorenzzetti, \& C. L. Jr Silva, 1995. Observações por satélite da ressurgência de Cabo Frio. In: Memórias do VII Simpósio Latinoamericano de Percepción Remota, Puerto Vallarta: 269-275.

Stevens, B. G., D. A. Armstrong \& J. C. Hoeman, 1984. Diel activity of an estuarine population of dungeness crabs, Cancer magister, in relation to feeding and environmental factors. Journal of Crustacean Biology 4: 390-403.

Sumida, P. Y. G., M. Y. Yoshinaga, A. M. Ciotti \& S. A. Gaeta, 2005. Benthic response to upwelling events of the SE Brazilian coast. Marine Ecology Progress Series 291: 35-42.

Ter Braak, C. J. F., 1996. Unimodal Models to Relate Species to Environment. DLO-Agricultural Mathematics Group, Wageningen: 266.

Tucker, M., 1988. Techniques in Sedimentology. Blackwell Scientific Publications, Boston: 394.

Watling, L. \& E. A. Norse, 1998. Disturbance of the seabed by mobile fishing gear: a comparison to forest clearcutting. Conservation Biology 12: 1180-1197.

Valentin, J. L. \& W. M. Monteiro-Ribas, 1993. Zooplankton community structure on the east-southeast Brazilian continental shelf $\left(18-23^{\circ} \mathrm{S}\right.$ latitude). Continental Shelf Research 13: 407-424.

Vega-Pérez, L. A., 1993. Estudo do zooplâncton da região de Ubatuba, Estado de São Paulo. Publicação especial do Instituto oceanográfico, São Paulo 10: 65-84. 